\title{
UJI EFEKTIVITAS BEBERAPA BAHAN PERANGKAP ORGANIK TERHADAP POPULASI WALANG SANGIT (Leptocorisa oratorius) PADA TANAMAN PADI
}

\author{
Oleh: \\ Yuliani*) \\ Sadiah**) \\ Widya Sari*) \\ Email : yuliani.sains@,unsur.ac.id
}

\begin{abstract}
ABSTRAK
Salah satu hama utama pada tanaman padi adalah walang sangit (Leptocorisa oratorius). Walang sangit merusak dengan cara menghisap cairan yang ada pada bulir padi pada saat bulir memasuki fase matang susu sehingga bulir padi akan menjadi hampa. Salah satu cara pengendalian hama walang sangit ialah dengan menggunakan perangkap dengan menggunakan berbagai umpan dari bahan organik dengan aroma menyengat seperti terasi, kulit udang, keong mas, dan bunga refugia. Penelitian ini bertujuan untuk mengetahui preferensi walang sangit terhadap beberapa bahan perangkap organik. Penelitian ini dilaksanakan pada bulan Maret 2020 bertempat di areal persawahan tanaman padi di Kecamatan Mande, Cianjur. Penelitian ini menggunakan Rancangan Acak Lengkap (RAL) dengan lima perlakuan dan tiga kali ulangan, perangkap yang digunakan dalam penelitian terdiri dari perangkap keong mas, limbah udang, terasi dan bunga refugia. Hasil penelitian ini memperlihatkan bahwa perangkap terasi sangat disukai oleh walang sangit, hal ini terlihat dari jumlah populasi walang sangit tertinggi berada pada perangkap ini baik pada minggu pertama maupun minggu ke dua.
\end{abstract}

Kata Kunci : Walang sangit (Leptocorisa oratorius), perangkap, terasi, bunga refugia, Keong Mas, limbah udang.

\begin{abstract}
One of the main pests on rice plants is the stink bug (Leptocorisa oratorius). Stink bugs are a major pest on rice plantation. Stink bugs damage by sucking the liquid that is in the rice grains when the grains enter the mature phase of milk so that the grains will become empty. Stink bugs can be controlled by using traps, which consist of organic ingredients such as: shrimp paste, shrimp shells, golden snails, and refugia flowers. The purpose of this study was to determine the preference of $L$. oratorius on several organic trap materials. This research was conducted in March 2020 in a rice field area in Mande District, Cianjur. This study used a completely randomized design (CRD) with five treatments and three replications, the materials used for traps in the study consisted of shrimp paste traps, shrimp shells, golden snails, and refugia flowers. The results of this study showed that the shrimp paste trap was very favored by the stink bugs, this could be seen from the highest population of walang sangit in this trap both in the first week and the second week.

Keywords : The stink bug (Leptocorisa oratorius), traps, shrimp paste, refugia flower, golden snail, shrimp waste.

*) Dosen Fakultas Sains Terapan UNSUR.

**) Alumni Fakultas Sains Terapan UNSUR.
\end{abstract}

\begin{tabular}{l}
\hline UJI EFEKTIVITAS BEBERAPA BAHAN \\
PERANGKAP ORGANIK TERHADAP \\
POPULASI WALANG SANGIT \\
oratorius) PADA TANAMAN PADI
\end{tabular}

YULIANI, SADIAH dan WIDYA SARI 


\section{PENDAHULUAN}

Indonesia merupakan sebagai suatu negara dengan jumlah penduduk yang besar dalam menghadapi tantangan untuk memenuhi kebutuhan pangan bagi penduduk. Terutama pada padi yang merupakan salah satu komoditas utama dalam menyokong pangan masyarakat Indonesia. Tanaman padi (Oryza sativa L.) merupakan tanaman pangan penting yang telah menjadi sebagai sumber makanan pokok dan lebih dari setengah penduduk dunia (Anggraini et al., 2013).

Kebutuhan beras sebagai salah satu sumber pangan utama penduduk Indonesia kini terus meningkat, karena selain meningkatnya penduduk yang terus bertambah dengan peningkatan sekitar $2 \%$ pertahun, tetapi juga adanya perubahan pola konsumsi penduduk dari non beras ke beras (Adriani, 2018 dalam Satria et al., 2017). Salah satu kendala pada permasalahan tersebut yaitu hama utama padi yang dapat menurunkan produksi tanaman padi adalah hama walang sangit. Walang sangit dapat merusak dengan cara menghisap cairan yang ada pada bulir padi pada saat bulir memasuki fase matang susu sehingga bulir padi akan menjadi hampa (Santoso, 2015)

Hama Walang sangit ini dapat menyebabkan kehilangan hasil dengan mencapai 50\%. Diperkirakan bahwa pada populasi 100.000 ekor perhektar dapat menurunkan hasil sampai $25 \%$. Hasil penelitian yang telah dilakukan dengan menunjukkan bahwa populasi walang sangit dengan 5 ekor per 9 rumpun padi akan menurunkan hasil 15\%. Hal ini karena, hubungan antara kepadatan populasi walang sangit dengan penurunan hasil menunjukkan bahwa serangan satu ekor walang sangit per malai dalam satu minggu dapat menurunkan hasil 27\% (Balai Besar Penelitian Tanaman Padi, 2009). Hama walang sangit harus dikendalikan agar tidak terjadi penurunan kualitas maupun kuantitas hasil produksi padi. Pengendalian walang sangit dapat dilakukan dengan melakukan sanitasi lingkungan, kultur teknis, secara biologi (menggunakan agens hayati), menggunakan perangkap, dan secara kimiawi (Azzamy, 2016).

Terdapat beberapa cara pengendalian walang sangit ialah dengan bau busuk menyengat, hal ini pernah dilakukan oleh Qomarodin (2006), yang menjelaskan tentang pengendalian walang sangit dengan bau busuk keong mas atau siput murbai mampu menurunkan serangan walang sangit. Bau busuk keong mas atau siput murbai bukan mematikan hama Walang sangit tetapi hanya sebagai pengalih perhatian sehingga dapat menghindari serangan hama tersebut pada padi. Penggunaan perangkap organik dari limbah udang dan bunga refugia belum pernah dilakukan, untuk itulah penulis mengambil topik penelitian tentang pengendalian hama walang sangit menggunakan keong mas, limbah kulit udang, terasi, dan bunga refugia. 


\section{METODE PENELITIAN}

Penelitian ini dilakukan pada bulan Maret 2020. Bertempat di areal persawahan tanaman padi di Desa Kademangan Kecamatan Mande.

Penelitian ini menggunakan Rancangan Acak Lengkap (RAL) dengan lima perlakuan dan tiga kali ulangan, perangkap keong mas dan limbah udang dibiarkan membusuk sampai mengeluarkan bau yang menyengat kecuali terasi, karena terasi sudah memiliki bau yang sangat menyengat, dan bunga refugia yang masih segar di ambil hanya bunganya saja. Kelima bahan untuk perangkap yang digunakan dalam penelitian ini adalah :

A : Perangkap terasi

B : Perangkap limbah udang

C : Perangkap keong mas

D : Perangkat bunga refujia

E : Tanpa perlakuan

Pengamatan dilakukan setiap hari selama penelitian. Sample didapat dengan cara mengambil hama yang terperangkap pada masing-masing perangkap yang ada pada lahan tanaman padi, kemudian pengamatan diamati dengan menghitung jumlah populasi walang sangit yang terperangkap.

Parameter yang diamati dalam peneltian ini yaitu populasi walang sangit yang terperangkap pada setiap perlakuan. Walang sangit di ambil pada setiap hari pada pagi hari dan setiap hari bahan orgaik setiap perlakuan perangkap diganti. Pengamatan dilakukan setiap hari pada pagi hari selama dua minggu (14 hari). Walang sangit diambil apabila terperangkap pada perlakuan.

Data yang diperoleh dan diolah menggunakan software Microsof Excell dan Minitab, untuk melihat pengaruh dari beberapa jenis perangkap terhadap hama walang sangit padi yang terperangkap, setelah itu dilakukan pengujian Hipotesis dengan uji Tukey pada taraf 5\%.

\section{HASIL DAN PEMBAHASAN}

\section{Jumlah Rata-Rata Hama Walang Sangit}

Parameter yang diamati pada penelitian ini adalah populasi hama walang sangit (Leptocorisa acuta T.) pada berbagai perangkap organik di areal tanaman padi. Hasil penelitian menggunakan perangkap organik pada hari pertama tidak berpengaruh nyata pada walang sangit sampai dengan hari ke empat, dan pada hari kelima berpengaruh nyata pada walang sangit. Semua data hasil pengamatan dilakukan pengujian secara statistik menggunakan uji ANOVA dan dilanjutkan uji lanjut Tukey pada taraf $\alpha$ 0,05 (Lampiran1) pada setiap hari pengamatan di minggu pertama (Tabel 1). 
Tabel 1. Jumlah Populasi Walang Sangit pada Masing-masing Perangkap Organik di Minggu Pertama.

\begin{tabular}{lccccccc}
\hline Jenis & \multicolumn{7}{c}{ Populasi Walang Sangit (hari ke-) } \\
\cline { 2 - 8 } Perangkap & $\mathbf{1}$ & $\mathbf{2}$ & $\mathbf{3}$ & $\mathbf{4}$ & $\mathbf{5}$ & $\mathbf{6}$ & $\mathbf{7}$ \\
\hline $\mathrm{A}$ & $0,67 \mathrm{a}$ & $1,33 \mathrm{a}$ & $3,33 \mathrm{a}$ & $5,67 \mathrm{a}$ & $6,67 \mathrm{a}$ & $5,67 \mathrm{a}$ & $5,33 \mathrm{a}$ \\
$\mathrm{B}$ & $0 \mathrm{a}$ & $0 \mathrm{a}$ & $0,33 \mathrm{a}$ & $2,33 \mathrm{a}$ & $1,33 \mathrm{~b}$ & $1,67 \mathrm{~b}$ & $1,33 \mathrm{~b}$ \\
$\mathrm{C}$ & $0 \mathrm{a}$ & $0 \mathrm{a}$ & $0,67 \mathrm{a}$ & $0 \mathrm{a}$ & $0 \mathrm{~b}$ & $1 \mathrm{~b}$ & $0,67 \mathrm{~b}$ \\
$\mathrm{D}$ & $0 \mathrm{a}$ & $0 \mathrm{a}$ & $0 \mathrm{a}$ & $0 \mathrm{a}$ & $0 \mathrm{~b}$ & $0 \mathrm{~b}$ & $0 \mathrm{~b}$ \\
$\mathrm{E}$ & $0 \mathrm{a}$ & $0 \mathrm{a}$ & $0 \mathrm{a}$ & $0 \mathrm{a}$ & $0 \mathrm{~b}$ & $0 \mathrm{~b}$ & $0 \mathrm{~b}$ \\
\hline
\end{tabular}

Keterangan : Angka yang diikuti dengan huruf yang sama pada kolom yang sama tidak berbeda nyata pada taraf $5 \%$ uji tukey. A : perangkap terasi, B : perangkap udang, $\mathrm{C}$ : perangkap keong mas, $\mathrm{D}$ : perangkap bunga refugia, $\mathrm{E}:$ control.

Hasil penelitian pada table 1. menunjukkan pada pengamatan hari pertama perlakuan perangkap dari berbagai perangkap tidak berbeda nyata, akan tetapi pengaruh yang lebih baik terdapat pada perangkap A (terasi) dengan nilai rata-rata 0,67 ekor walang sangit, dan pada perangkap B (kulit udang), C (keong mas), D (refugia), dan $\mathrm{E}$ (kontrol) belum menunjukkan adanya pengaruh yang nyata dengan rata-rata 0 ekor walang sangit.

Hari kedua pengamatan tidak berbeda nyata, akan tetapi pengaruh yang lebih baik terdapat pada perangkap A (terasi) dengan nilai rata-rata 1,33 ekor walang sangit, dan pada perangkap B (kulit udang), C (keong mas), D (refugia), dan E (kontrol) belum menunjukkan adanya pengaruh yang nyata dengan rata-rata 0 ekor walang sangit.

Hari ketiga pengamatan tidak berbeda nyata, akan tetapi pengaruh yang lebih baik terdapat pada perangkap A (terasi) dengan rata-rata 3,33 ekor walang sangit, dan pengaruh yang lebih baik juga terdapat pada perangkap $C$ (keong mas) dengan ratarata 0,67 ekor walang sangit, dan terdapat pada perangkap B (kulit udang ) dengan nilai rata-rata 0,33 ekor walang sangit, pada perangkap D (refugia) dan E (kontrol) belum menunjukkan adanya pengaruh nyata pada hama walang sangit dengan nilai rata-rata 0 ekor walang sangit.

Hari keempat pengamatan tidak berbeda nyata, akan tetapi pengaruh yang lebih baik terdapat pada perangkap A (terasi) dengan rata-rata 5,67 ekor walang sangit, dan pengaruh yang lebih baik juga terdapat pada perangkap B (kulit udang) dengan ratarata 2,33 ekor walang sangit, dan pada perangkap C (keong mas), D (refugia), dan E (kontrol) belum menunjukkan pengaruh nyata pada hama walang sangit dengan ratarata 0 ekor walang sangit.

Hari kelima pemasangan perangkap organik sudah terlihat perbedaan nyata dengan rata-rata tertinggi terperangkapnya hama walang sangit pada perangkap A (terasi) sebesar 6,67 ekor walang sangit dan perangkap B (kulit udang) dengan ratarata 1,33 ekor walang sangit, sedangkan perangkap lainnya seperti perangkap $C$ (keong mas), D (refugia), dan E (kontrol), belum berpengaruh terhadap hama walang sangit dengan rata-rata 0 ekor walang sangit. 
Hari keenam pemasangan perangkap organik sudah terlihat perbedaan nyata dengan rata-rata tertinggi terperangkapnya hama walang sangit pada perangkap A (terasi) sebesar 5,67 ekor walang sangit, dan perangkap yang tertinggi pada perangkap B (kulit udang) dengan rata-rata 1,67 ekor walang sangit dan perangkap C (keong mas) dengan rata-rata 1 ekor walang sangit, sedangkan perangkap lainnya seperti perangkap D (refugia) dan E (kontrol) belum berpengaruh terhadap hama walang sangit dengan rata-rata 0 ekor walang sangit.

Hari ketujuh pemasangan perangkap sudah terlihat perbedaan nyata dengan rata-rata tertinggi terperangkapnya hama walang sangit pada perangkap A (terasi) sebesar 5,33 ekor walang sangit, dan perangkap yang tertinggi pada perangkap B (kulit udang) dengan rata-rata 1,33 ekor walang sangit dan perangkap C (keong mas) dengan rata-rata 0,67 ekor walang sangit, sedangkan perangkap lainnya seperti perangkap D (refugia) dan E (kontrol) belum berpengaruh terhadap hama walang sangit dengan rata-rata 0 ekor walang sangit.

Hari pertama pada minggu ke dua pemasangan perangkap sudah mengalami perubahan yang signifikan dengan nilai $\mathrm{p}$-value 0,00 lebih kecil dari pada $\alpha 0,05$. (terlihat pada Tabel 2) pada setiap hari pengamatan di minggu kedua.

Tabel 2. Jumlah Populasi Walang Sangit pada Masing-masing Perangkap Organik pada Minggu ke dua.

\begin{tabular}{lccccccc}
\hline Jenis & \multicolumn{7}{c}{ Populasi Walang Sangit (hari ke-) } \\
\cline { 2 - 8 } Perangkap & $\mathbf{1}$ & $\mathbf{2}$ & $\mathbf{3}$ & $\mathbf{4}$ & $\mathbf{5}$ & $\mathbf{6}$ & $\mathbf{7}$ \\
\hline $\mathrm{A}$ & $4,67 \mathrm{a}$ & $6,67 \mathrm{a}$ & $4,67 \mathrm{a}$ & $4,67 \mathrm{a}$ & $5,33 \mathrm{a}$ & $5,33 \mathrm{a}$ & $4,67 \mathrm{a}$ \\
$\mathrm{B}$ & $1,33 \mathrm{~b}$ & $0,33 \mathrm{~b}$ & $0,67 \mathrm{~b}$ & $0,33 \mathrm{~b}$ & $1,33 \mathrm{~b}$ & $1,32 \mathrm{~b}$ & $0,67 \mathrm{~b}$ \\
$\mathrm{C}$ & $0 \mathrm{~b}$ & $0 \mathrm{~b}$ & $1,33 \mathrm{~b}$ & $0,33 \mathrm{~b}$ & $0,67 \mathrm{~b}$ & $2 \mathrm{~b}$ & $1 \mathrm{~b}$ \\
$\mathrm{D}$ & $0 \mathrm{~b}$ & $0 \mathrm{~b}$ & $0 \mathrm{~b}$ & $0 \mathrm{~b}$ & $0 \mathrm{~b}$ & $0 \mathrm{~b}$ & $0 \mathrm{~b}$ \\
$\mathrm{E}$ & $0 \mathrm{~b}$ & $0 \mathrm{~b}$ & $0 \mathrm{~b}$ & $0 \mathrm{~b}$ & $0 \mathrm{~b}$ & $0 \mathrm{~b}$ & $0 \mathrm{~b}$ \\
\hline
\end{tabular}

Keterangan : Angka yang diikuti dengan huruf yang sama pada kolom yang sama tidak berbeda nyata pada taraf 5\% uji tukey. A : perangkap terasi, B : perangkap udang, $\mathrm{C}$ : perangkap keong mas, D : perangkap bunga refugia, E : control.

Pada hari pertama di minggu kedua pengaruh perangkap yang lebih baik adalah perangkap A (terasi) dengan rata-rata 4,67 ekor walang sangit disertai dengan perangkap B (kulit udang) dengan rata-rata 1,33 ekor walang sangit, dan perangkap yang kurang baik terdapat pada perangkap C (keong mas), D (refugia) dan E (kontrol) dengan rata-rata 0 ekor walang sangit.

Pada hari kedua pemasangan perangkap diperoleh hasil yang signifikan dengan nilai $\mathrm{p}$-value 0,00 lebih kecil dari pada $\alpha 0,05$. Pengaruh perangkap yang lebih baik adalah perangkap A (terasi) dengan rata-rata 6,67 ekor walang sangit, disertai dengan perangkap B (kulit udang) dengan rata-rata 0,33 ekor walang sangit, dan perangkap yang kurang baik terdapat pada perangkap C (keong mas), D (refugia), E (kontrol) dengan rata-rata 0 ekor walang sangit.

Hari ketiga pemasangan perangkap diperoleh hasil yang signifikan dengan nilai P-Value 0,001 lebih kecil dari pada $\alpha$ 0,05. Pengaruh perangkap yang lebih baik adalah perangkap A (terasi) dengan nilai rata-rata 4,67 ekor walang sangit, disertain 
dengan perangkap $\mathrm{C}$ (keong mas) dengan rata-rata 1,33 ekor walang sangit, dan perangkap yang kurang baik terdapat pada perangkap B (kulit udang) dengan rata-rata 0,67 ekor walang sangit, perangkap D (refugia) dengan nilai rata-rata 0 ekor walang sangit, dan perangkap E (kontrol) dengan rata-rata 0 ekor walang sangit.

Hari keempat pemasangan perangkap diperoleh hasil yang signifikan dengan nilai $\mathrm{p}$-value 0,000 lebih kecil dari pada $\alpha 0,05$. Pengaruh perangkap yang lebih baik adalah perangkap A (terasi) dengan rata-rata 4,67 ekor walang sangit, disertai dengan perangkap B (kulit udang) dengan rata-rata 0,33 ekor walang sangit, perangkap C (keong mas) dengan rata-rata 0,33 ekor walang sangit, dan perangkap yang kurang baik terdapat pada perangkap D (refugia) dengan rata-rata 0 ekor walang sangit, dan E (kontrol) 0 ekor walang sangit.

Hari kelima pemasangan perangkap diperoleh hasil yang signifikan dengan nilai p-value 0,000 lebih kecil dari pada $\alpha 0,05$. Pengaruh perangkap yang lebih baik adalah perangkap A (terasi) dengan rata-rata 5,33 ekor walang sangit, disertai dengan perangkap B (kulit udang) 1,33 ekor walang sangit, dan perangkap yang kurang baik terdapat pada perangkap $C$ (keong mas) dengan rata-rata 0,33 ekor walang sangit, perangkap D (refugia) dengan rata-rata 0 ekor walang sangit, dan $\mathrm{E}$ (kontrol) dengan rata-rata 0 ekor walang sangit .

Hari keenam pemasangan perangkap diperoleh hasil yang signifikan dengan nilai p-value 0,000 lebih kecil dari pada $\alpha 0,05$. Pengaruh bahan perangkap yang lebih baik adalah perangkap A (terasi) dengan rata-rata 5,33 ekor walang sangit, dan disertai dengan perangkap yang kurang baik terdapat pada perangkap B (kulit udang) dengan rata-rata 1,32 ekor walang sangit, perangkap $C$ (keong mas) dengan rata-rata 0,67 ekor walang sangit, perangkap D (refugia) dengan rata-rata 0 ekor walang sangit, dan $\mathrm{E}$ (control) dengan rata-rata 0 ekor walang sangit.

Hari ketujuh pemasangan perangkap diperoleh hasil yang signifikan dengan nilai $\mathrm{p}$-value 0,000 lebih kecil dari pada $\alpha 0,05$. Pengaruh bahan perangkap yang lebih baik adalah perangkap A (terasi) dengan rata-rata 4,67 ekor walang sangit dan disertai dengan perangkap yang kurang baik terdapat pada berangkap C (keong mas) dengan rata-rata 1 ekor walang sangit, perangkap B (kulit udang) 0,67, perangkap D (refugia) dengan rata-rata 0 ekor walang sangit, dan $\mathrm{E}$ (kontrol) 0 ekor walang sangit.

Berdasarkan tabel 1. dan 2. perangkap organik menggunakan terasi sangat berpengaruh nyata terhadap rata-rata populasi walangsangit dan berbeda nyata dengan perangkap organik lain, seperti perangkap kulit udang, perangkap keong mas, bunga refugia, dan kontrol. Hal ini diduga terasi mempunyai senyawa volatile yang paling kuat diantara jenis perangkap organik lainnya, Menurut (Hadiwiyanto, 1993 dalam Kaparang et al., 2013), Terasi memiliki bau yang sangat khas, tajam dan merangsang. Bau ini timbul selama terasi mangalami proses penyimpanan atau fermentasi. selama fermentasi mikroba mampu mengadakan tranformasi senyawasenyawa kimia, sehingga dihasilkan senyawa turunannya yang bersifat volatile. Transformasi ini dapat berupa hidroksilasi, oksidasi, pemecahan rantai karbon atau

\begin{tabular}{l}
\hline UJI EFEKTIVITAS BEBERAPA BAHAN \\
PERANGKAP ORGANIK TERHADAP
\end{tabular}


reduksi. Senyawa volatile ini yang diduga menjadi faktor ketertarikan walangsangit terhadap terasi.

Walang sangit (Leptocorisa spp.) menyerang pada bagian buah padi yang dalam keadaan matang susu sehingga bulirnya menjadi hampa. Hama ini bukan hanya dapat menurunkan hasil tetapi juga menurunkan kualitas gabah seperti bintik-bintik coklat pada gabah akibat isapan cairan dari hama tersebut. Selain daripada itu, serangan terberat dapat menurunkan produksi hingga tidak dapat di panen. Menurut Pracaya (2009) dengan menyatakan bahwa walang sangit ini biasanya bertelur pada waktu sore hari atau senja. Pada umumnya telur tersebut diletakkan pada bagian permukaan daun di dekat malai yang segera muncul. Hal ini, tujuannya agar pada waktu menetas nimfa segera dapat mengisap malai yang masih masak susu.

Tanaman inang selain padi yang sangat disukai walang sangit antara lainnya yaitu sorghum, tebu, gandum. Sedangkan pada berbagai jenis rumput, di antaranya yaitu Italica, Setaria, Panicum crus-galli, Panicum colonum, Panicum flavidum, Panicum miliare, Eleusine coracana, Setaria glauca.

Walang sangit sangat rentan yang menyerang pada Fase generatif yaitu masa bunga padi pada umumnya mengalami penyerbukan sendiri, namun kadang - kadang penyerbukan silang. Penyerbukan silang berkisar antara $1 \%-5 \%$, yang dimana pemasakan butir malai ada 4 stadia yaitu masak susu, masak kuning, masak penuh dan masak mati. Fase generatif tanaman padi varietas Ciherang terjadi antara umur 60-100 hari setelah tanam dan Anak Daro antara umur 90-120 hari setelah tanam (Amanina, 2011)

Berdasarkan hasil penelitian (Asikin dan Thamrin, 2009) menyatakan bahwa di lahan rawa lebak petani dalam mengendalikan hama khususnya walang sangit yaitu dengan menggunakan perangkap yang berasal dari bahan keong dengan cara dibusukkan. Cara pengendalian tersebut, dapat menekan terjadinya intensitas kerusakan tanaman padi yang diakibatkan oleh serangan walang sangit. Bahan-bahan yang membusuk ini mengandung senyawa volatile, yaitu senyawa yang mudah menguap. Senyawa volatile ini menguap dan menyebar hingga tercium oleh walang sangit. Walang sangit tertarik ini kemudian akan mendatangi umpan yang membusuk (Yudono, 2007).

Sudah diketahui sejak lama bahwa walang sangit ini tertarik dengan bahanbahan yang membusuk, bahkan petani pun sudah banyak yang memanfaatkannya untuk mengendalikan populasi walang sangit tersebut. Salah satu caranya yaitu dengan memasang bahan-bahan yang sedang membusuk seperti terasi, burus, kepiting, kotoran ayam serta beberapa gulma air di dekat malai. Sampai saat ini belum dapat diketahui mengapa walang sangit sanagt menyukai bahan-bahan tersebut, tetapi diduga hal ini diperantarai oleh kandungan senyawa volatile (Solikhin, 2000).

Identifikasi senyawa-senyawa volatile yang menarik serangga (hama) sangat penting dilakukan dalam rangka pengelolaan serangga hama sehingga usaha ini nanti akan menjadi sangat penting dalam rangka pengelolaan hama terpadu yang tidak hanya bertumpu pada penggunaan pestisida sintetik organik. Tetapi salah satu hal

\begin{tabular}{|c|c|}
\hline EFEKTIVITAS & YULIANI, SADIAH dan WIDYA SARI \\
\hline $\begin{array}{l}\text { PERANGKAP ORGANIK } \\
\text { POPULASI WALANG SANGIT }\end{array}$ & \\
\hline
\end{tabular}


yang harus diperhatikan adalah keberadaan senyawa volatile (bau) dari tanaman atau bahan lainnya berada dalam keadaan campuran (Solikhin, 2000).

Komponen pada cita rasa yang terdapat diterasi dapat dipaparkan yaitu asam lemak yang bersifat volatil menyebabkan adanya bau keasaman, sedangkan amonia dan amin menyebabkan bau anyir. Selain daripada itu, senyawa belerang sederhana seperti pada sulfida, merkaptan dan disulfida menyebabkan bau yang merangsang pada terasi. Senyawa-senyawa pada karbonil besar sekali kemungkinannya dapat memberikan bau khusus yang terdapat pada hasil-hasil perairan yang diawetkan baik dengan cara pengeringan, penggaraman ataupun dengan cara fermentasi. Senyawasenyawa volatil yang terdapat dalam terasi berasal dari lemak melalui yang melalui sebuah proses oksidasi dengan adanya aktivitas mikroba. Kandungan karbonil volatil merupakan 14 kandungan senyawa volatil yang terbesar diantara komponen volatil lainnya. senyawa tersebut merupakan senyawa yang sangat menentukan citarasa dari terasi (Adawiyah, 2007).

Irianto (2013) menyatakan bahwa terdapat 138 komponen volatile pada terasi masak yang terdiri dari 16 hidrokarbon, 7 alkohol, 46 karbonil, 7 asam lemak, 3 ester, 34 senyawa nitrogen, 15 senyawa sulfur dan 10 senyawa lainnya. Asam lemak volatil dapat memberikan bau keasaman, sedangkan amonia dan senyawa amin dengan menghasilkan bau amoniak. Senyawa-senyawa sulfur seperti H2S, merkaptan sulfit dan bisulfit yaitu dengan memberikan karakteristik bau terasi yang menusuk. Walaupun kulit udang tidak sebaik perangkap terasi, kulit udang juga mampu menarik hama walang sangit dengan adanya senyawa volatile pada kulit udang.

Ketertarikan beberapa spesies serangga terhadap senyawa volatile dipengaruhi oleh jenis kelaminnya. Sebagai contoh, ngengat betina Trichoplusa ni Hubner menyukai senyawa volatile fenilasetaldehid, 25 spesies dari genus Bactrocera (jantan) menyukai metil eugenol, dan nyamuk betina serta beberapa serangga pengisap darah lainnya menyukai CO2. Sementara itu, walang sangit jantan dalam jumlah massal sering didapati mengumpul pada binatang yang membusuk dan beberapa gulma (Solikhin, 2000).

Bau busuk yang ditimbulkan udang pada akhir penyimpanan disebabkan karena menguapnya basa-basa volatile yang disebabkan oleh degradasi protein sehingga terbentuknya senyawa amoniak yang akan memberikan bau busuk, hal ini diperkuat oleh (Farahita et al., 2012), bakteri yang merombak protein akan menghasilkan enzim proteolitik yang mengakibatkan protein menjadi ikatan peptida yang pendek dan asam amino yang terbentuk menjadi senyawa amin dan amoniak yang akan memberikan bau tajam dan cita rasa yang khas.

Bunga refugia merupakan bunga yang memiliki mikrohabitat dengan menyediakan tempat untuk berlindung bagi musuh alami dan adanya musuh alami dapat melemahkan reproduksi OPT. Hal ini, bertujuan untuk mengetahui jenis serangga yang datang pada bunga refugia warna putih, merah muda, kuning dan jingga (Adawiyah et al., 2020). Tanaman refugia yang banyak tumbuh yaitu bunga kenikir (Cosmos caudatus), bunga kertas (Zinnia sp), bunga matahari (Helianthus

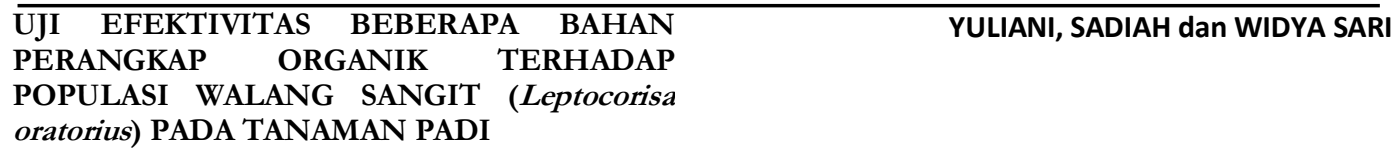


annuus L. ), bunga jengger ayam (Celosia cristata) dan bunga jengger ayam kipas (Celosia plumosa). Tanaman refugia ini memiliki sifat yang mudah tumbuh, cepat berkembang dan mempunyai warna serta aroma khas yang sangat disukai oleh serangga tersebut. Berbagai jenis refugia tumbuh subur dan melimpah. Namun, selama ini petani belum dapat mengetahui manfaat dari tanaman tersebut (Septiarini et al., 2019).

\section{PENUTUP}

\section{Kesimpulan}

Penggunaan beberapa perangkap organik berpengaruh terhadap jumlah populasi hama walang sangit yang terperangkap baik pada minggu pertama maupun minggu ke dua pengamatan. Perangkap yang banyak memerangkap hama walang sangit adalah perangkap terasi, sedangkan untuk perangkap lainnya seperti perangkap kulit udang, keong mas, bunga refugia, kurang disukai oleh Walang sangit dan tidak berbeda nyata dengan kontrol.

\section{Saran}

Berdasarkan hasil penelitian yang telah dilakukan, maka ada beberapa saran yang harus dilakukan oleh peneliti selanjutnya yaitu :

1. Perlu dilakukan penelitian lanjutan terhadap populasi walang sangit pada varietas yang berbeda selain varietas padi ciherang.

2. Perlu dilakukan penelitian lanjutan untuk melihat preferensi Walang sangit terhadap perangkap organik pada instar nimfa yang sama.

\section{DAFTAR PUSTAKA}

Azzamy. (2016). "5 Cara Ampuh Mengendalikan Hama Walang Sangit Secara Alami Dan Kimiawi." Retrieved January 13, 2020 (https://mitalom.com/cara-tepatmengendalikan-hama-walang-sangit-pada-tanaman-padi/).

Asikin, S., dan Thamrin, M. (2009). Pengendalian Hama Walang Sangit (Leptocorisa oratorius F) di Tingkat Petani Lahan Lebak Kalimantan Selatan. https://anzdoc.com/queue/pengendalian-hama-walang-sangitleptocorisaoratorius-f-di-t.html.pdf.

Adawiyah, R. (2007). Pengolahan dan Pengawetan Ikan. PT Bumi Aksara. Jakarta.

Adawiyah, R. Aphrodyanti, L. Aidawati, N. (2020). "Pengaruh Warna Bunga Refugia Terhadap Keanekaragaman Serangga Pada Pertanaman Tomat (Solanum lycopersicum)." J. Proteksi Tanaman Tropika 3(02).

Anggraini F, Agus S, dan Nurul A. (2013). Sistem Tanam dan Umur Bibit pada Tanaman Padi Sawah (Oryza sativa L.) Varietas Inpar 13. J. Produksi Tanaman, 1 (2).

Amania, M. A. 2011. Pengaruh Pemberian Strain Nostok Cpg8, Cpg24 Dan Cim7 Terhadap Pertumbuhan Vegetatif Dan Generatif Tanaman Padi (Oriza sativa L.) varietas ciherang. Skripsi. Universitas Indonesia.

\begin{tabular}{l}
\hline UJI EFEKTIVITAS BEBERAPA BAHAN \\
PERANGKAP ORGANIK TERIANI, SADIAH dan WIDYA SARI \\
POPULASI WALANG SANGIT \\
oratorius) PADA TANAMAN PADI
\end{tabular}


Balai Besar Penelitian Tanaman Padi. (2009). Hama WalangSangit (Leptcorisa oratorius). Diakses darihttp://bbpadi.litbang.deptan.go.id/ pada tanggal 18 September 2016, Medan.

Conceicao, L.M.D. (2009). Efektifitas Penggunaan Bangkai Yuyu, Katak dan Tikus Sebagai Atraktan Walang Sangit (Leptocorisa acuta Thunberg.). Skripsi. Universitas Atma Jaya. Yogyakarta

FarahitaY, Julianto N. Kurniawati. (2012). Karakteristik kimia Caviar Nilem dalam perendaman campuran larutan asam asetat dengan larutan garam selama penyimpanan suhu dingin (5-10 $\left.{ }^{\circ} \mathrm{C}\right)$. Jurnal Perikanan dan Kelautan. 3(4): 165-170.

Irianto E. (2013). Produk Fermentasi Ikan. Swadaya : Bandung

Kalshoven, L. G. E. (1981). The Pest of Crops in Indonesia. Resived and Translate by P. A van der laan. PT. Ichtiar Baru-van hoeve, Jakarta.

Kaparang, R. Harikedua, D, S. Suwetja, K, I. (2013). Penentuan Mutu Ikan Tandipang (Dossumieria acuta C.V) Asap Kering selama Penyimpanan Suhu Kamar. J. Media Teknologi Hasil Perikanan 1 (1).

Pratimi, A., dan Soesilohadi, R. C. H. (2011). Fluktuasi Populasi Walang Sangit Leptocorisa oratorius F. (Hemiptera: Alydidae) Pada Komunitas Padi Di Dusun Kepitu, Sleman, Daerah Istimewa Yogyakarta. Bioma. 13(2) : 54-59

Purwono, Purnamawati H. (2007). Budidaya 8 Jenis Tanaman Pangan Unggul. Penebar Swadaya. Jakarta.

Pracaya. (2008). Pengendalian Hama dan Penyakit Tanaman Secara Organik. Kanisius. Yogyakarta.

Rivo M., Christina L.S , Juliet E.M dan Mamahit, E.S. (2013). Padat Populasi Dan Intensitas Serangan Hama Walang Sangit (Leptocorisa Acuta Thunb.) Pada Tanaman Padi Sawah Di Kabupaten Minahasa Tenggara. Cocos, 2(3).

Santoso, Rachmat S. (2015). Asap Cair Sabut Kelapa Sebagai Repelan Bagi Hama Padi Walang Sangit ( Leptocorisa oratorius ). Jurnal Sainsmat, IV(2):81-86.

Septariani, N, D. Herawati, A. Mujiyo. (2019). Pemanfaatan Berbagai Tanaman Refugia sebagai Pengendali Hama Alami pada Tanaman Cabai (Capsicum annum L.). Journal of Community Empowering a Services, 3(1).

Solikhin. (2000). Ketertarikan Walang Sangit (Leptocorisa oratorius F.) Terhadap Beberapa Bahan Organik yang Membusuk. J. Hama dan Penyakit Tumbuhan Tropika. 1(1):16-24.

Satria B, Erwin M, Jamilah. (2017). Peningkatan Produktivitas Padi Sawah (Oryza sativa L.) Melalui Penerapan Bebebrapa Jarak Tanam dan Sistem Tanam. J. Agroteknologi FP USU. 5 (3):629-637.

Winarno, F. G. (1993). Pangan : Giæi, Teknologi, dan Konsumen. Gramedia Pustaka Utama. Jakarta.

Yudono, D. A. (2007). Studi Kombinasi Bentuk Perangkap dan Atraktan Terhadap Potensi Perangkap Walangsangit (Leptocorisa acuta Thunberg). (Skripsi) Jurusan Hama danPenyakit Tumbuhan. Universitas Jember. Jember.

\begin{tabular}{l}
\hline UJI EFEKTIVITAS BEBERAPA BAHAN \\
PERANGKAP ORGANIK TERHADAP \\
POPULASI WALANG SANGIT \\
oratorius) PADA TANAMAN PADI
\end{tabular}

